\title{
Prevalence of oral hairy leukoplakia and epithelial infection by Epstein- Barr virus in pregnant women and diabetes mellitus patients - cytopathologic and molecular study
}

\author{
Adrianna Milagres, Eliane Pedra Dias $/{ }^{+}$, Débora dos Santos Tavares, \\ Roberta Miranda Cavalcante, Vivian Antunes Dantas, Silvia Paula de Oliveira, \\ José Paulo Gagliardi Leite*
}

\author{
Programa de Pós-graduação em Patologia, Hospital Universitário Antônio Pedro, Universidade Federal Fluminense \\ Rua Marquês de Paraná, 303 - 4 andar, sala 1, 24033-900 Niterói, RJ, Brasil *Laboratório de Virologia, \\ Instituto Oswaldo Cruz-Fiocruz, Rio de Janeiro, RJ, Brasil
}

\begin{abstract}
Oral hairy leukoplakia $(O H L)$ is generally reported in patients with severe immunosuppression, except for a few cases in individuals with moderate degree of immunodeficiency. It is a white lesion that appears mainly in the lateral border of the tongue, caused by Epstein-Barr virus (EBV). The nuclear changes caused by EBV (Cowdry A inclusion, ground glass and nuclear beading), observed in cytopathology, are specific and enough for the definitive diagnosis of $O H L$, independent of the identification of the virus. Here we investigated the prevalence of $O H L$ and the presence of EBV-DNA in the lateral borders of the tongue from 90 pregnant women, 90 diabetes mellitus (DM) patients, 30 healthy individuals (negative group) and $30 \mathrm{HIV+}$ with OHL (positive group). Smears were analyzed by cytopathology and polymerase chain reaction (PCR). A case of subclinical $O H L$ and candidiasis was identificated in a DM patient by cytopathologic analysis. PCR results demonstrated EBV-DNA in $65 \%$ of the pregnant women, in $35 \%$ of DM patients, and in $20 \%$ of the healthy individuals. We concluded that DM patients can develop OHL with a low prevalence. Furthermore, the prevalence of the EBV in lateral border of the tongue is larger in pregnant women than in healthy individuals.
\end{abstract}

Key words: oral hairy leukoplakia - pregnant - diabetes mellitus - Epstein-Barr virus - cytopathology - polymerase chain reaction

Oral hairy leukoplakia (OHL) is a white lesion caused by Epstein Barr virus (EBV) that occurs mainly in the lateral border of the tongue and it is often associated with severe immunodeficiency as in HIV infection, malignant tumor, and organ transplant recipients (Blomgren \& Bäck 1996, Ammatuna et al. 2001, Casiglia \& Woo 2002). However, according to the literature (Table I) there are cases of OHL in patients with moderate or minor immunosuppression (self-immune diseases) and also in immunocompetent individuals (Eisenberg et al. 1992, Felix et al. 1992, Lozada-Nur et al. 1994, Schiodt et al. 1995, Zakrzewska et al. 1995). Besides molecular methods to detect the presence of EBV in OHL suspect lesions, the diagnosis might be done through the identification of nuclear alterations that represent the cytopathic effect of EBV on keratinocytes: Cowdry A inclusion, ground glass and nuclear beading. Although these alterations are observed in both histopathological and cytopathological exams, the later one has been considered the best method to diagnose clinical and subclinical OHL (Fraga-Fernández \& Vicandi-Plaza 1992, Migliorati et al. 1993, Dias et al. 2000).

Financial support: Capes, $\mathrm{CNPq}$

+Corresponding author: mptepd@ vm.uff.br

Received 3 October 2006

Accepted 22 February 2007
There is only one disease associated with EBV replicative infection in immunocompetent patients: infectious mononucleosis. Moreover, latent infection has been associated with several malignant and benign tumors in which EBV identification appears only when the disease is already installed (Gulley 2001, Sand et al. 2002). Reports on the seroprevalence of EBV infection are usually taken in healthy subjects, with the seropositivity in 70-90\% (Ferres et al. 1995, Pancharoen et al. 2001, Ozkan et al. 2003). Nevertheless, the presence of EBV in oral epithelium has been investigated only by some authors: HIV-1 $1^{+}$subjects, prevalence of 11 to $67 \%$ (Mabruck et al. 1995, Scully et al. 1998, Triantos et al. 1998, Ammatuna et al. 2001), organ transplant recipients, 4-58\% (Schimidt-westhausen et al. 1993, Ammatuna et al. 2001) and on healthy individuals, 7 to $90 \%$ (Mabruk et al. 1994, Scully et al. 1998, Triantos et al. 1998, Ammatuna et al. 2001, Sand et al. 2002).

In diabetics, it has been observed a deficiency in polymorphonuclear leucocytes chemotaxy and abnormalities in phagocytic function of macrophages (Stiehm \& Fulginiti 1980). In pregnant women, there is a suppression in cellular immune response and a decrease in peripheral lymphocytes count indicating a diminish of CD4 $\mathrm{T}$ cells and a concomitant increase of CD8 T cells (Nakamura et al. 1993, Priddy 1997). Considering that there is little information referring to OHL in non immunocompromised individuals and the several malignant tumors associated with EBV, this work aimed to investigate the prevalence of OHL and EBV epithelial infection in pregnant women and diabetic patients, considered here as individuals with minor immunodeficiency. 
TABLE I

Hairy leukoplakia in immunocompetent patients and individuals with moderate or minor immunossupression

\begin{tabular}{|c|c|c|c|c|}
\hline Author & Cases & Sistemic condition & Corticotherapy & Diagnosis method \\
\hline Eisenberg (1992) & 2 & Immunocompetent & - & $\begin{array}{l}\text { Histopathology in situ } \\
\text { Hibridization }\end{array}$ \\
\hline Felix (1992) & 1 & Immunocompetent & - & $\begin{array}{l}\text { Histopathology in situ } \\
\text { Hibridization }\end{array}$ \\
\hline Lozada-Nur (1994) & $\begin{array}{l}1 \\
1 \\
2\end{array}$ & $\begin{array}{l}\text { Pemphigus } \\
\text { Pemphigoid } \\
\text { Immunocompetent }\end{array}$ & $\begin{array}{l}\text { Topic } \\
\text { Topic } \\
\text { - }\end{array}$ & $\begin{array}{l}\text { Histopathology in situ } \\
\text { Hibridization }\end{array}$ \\
\hline Schiodt (1995) & 1 & Behçet's syndrome & Oral & $\begin{array}{l}\text { Histopathology in situ } \\
\text { Hibridization }\end{array}$ \\
\hline Zakrzewska (1995) & 1 & Asthma & Inalation & $\begin{array}{l}\text { Histopathology in situ } \\
\text { Hibridization } \\
\text { Imunohistochemistry }\end{array}$ \\
\hline
\end{tabular}

\section{MATERIALS AND METHODS}

This work was approved by ethics committee, and comprised 90 DM patients (group $A$ ) and 90 pregnant women (group B) attending, respectively, the Endocrinology and Gynecology and Obstetrics Departments at Hospital Universitário Antonio Pedro (HUAP) and Hospital Maternidade Fernando Magalhães. It has also been established a negative control group composed of 30 clinically healthy individuals and HIV seronegative (group $C$ ), and a positive control group of 30 patients (group D) HIV seropositive with OHL cytopatological diagnosis (data obtained from the files of the Pathological Anatomy Service at HUAP).

Every patient was submitted to clinical anamnesis, oral examination and a smear of the lateral border of the tongue was collected using a sterile endocervical brush. The smears were then fixed in $96^{\circ} \mathrm{GL}$ alcohol and stained by Papanicolaou technique. The following aspects were evaluated by cytopathology: (a) cellularity (good or insufficient); (b) predominant cellular disposition (loose, in plaques, overlapped); (c) presence or absence of bacteria, polymorphonuclear (PMN), mononuclear (MN) cells and candidiasis; (d) presence or absence of Cowdry A inclusion, ground glass and nuclear beading.

After collecting the cytological samples, the brushes had their tips sectioned and conditioned into Eppendorf tubes containing a TBS solution stored at $-80^{\circ} \mathrm{C}$. The brushes from 20 patients from group A, 20 from group B, 10 from group C, and 2 from group D were randomly selected to be submitted to polymerase chain reaction (PCR) analysis and the human $\beta$-globin gene was amplified in order to assess the adequacy of the specimen. EBV-DNA was extracted by means of DNAZOL ${ }^{\circledR}$ (Invitrogen) technique. NESTED-PCR was performed in all samples previously selected. Two primer sets that amplified a $297 \mathrm{bp}$ or a $209 \mathrm{bp}$ fragments from the EBNA-1 gene were used on these reactions (Cinque et al. 1993, Read et al. 1997). After initial denaturation for $5 \mathrm{~min}$ at $94^{\circ} \mathrm{C}$ followed by $2 \mathrm{~min}$ on ice, PCR mixture was added to $10 \mu \mathrm{l}$ of the sample followed by the amplification program in the thermal cycler: $94^{\circ} \mathrm{C}$ for 2 min; 35 cycles $\left(94^{\circ} \mathrm{C}\right.$ for $30 \mathrm{~s}, 55^{\circ} \mathrm{C}$ for $30 \mathrm{~s}, 72^{\circ} \mathrm{C}$ for
$30 \mathrm{~s})$; one time $\left(72^{\circ} \mathrm{C}\right.$ for $\left.10 \mathrm{~min}\right) ; 10^{\circ} \mathrm{C}$ forever; $5 \mu \mathrm{l}$ of the PCR product was added to $45 \mu$ of the NESTED mixture with the following cycle on the thermal cycler: $94^{\circ} \mathrm{C}$ for $45 \mathrm{~s} ; 35$ cycles $\left(94^{\circ} \mathrm{C}\right.$ for $20 \mathrm{~s}, 55^{\circ} \mathrm{C}$ for $30 \mathrm{~s}$; $72^{\circ} \mathrm{C}$ for $\left.30 \mathrm{~s}\right)$; one time $\left(72^{\circ} \mathrm{C}\right.$ for $\left.10 \mathrm{~min}\right) ; 10^{\circ} \mathrm{C}$ forever. After this second amplification with inner primers, $10 \mu \mathrm{l}$ of the amplified product was electrophoresed on a $1.5 \%$ agarose gel containing ethidium bromide. The results were photographed under UV illumination and considered positive when a band corresponding to the 209 bp DNA fragment was present. The PCR mixture used contained dNTP's $(2,5 \mathrm{mM}$ - Invitrogen ()$)-4 \mu \mathrm{l} ; 10 \mathrm{X}$ buffer (Invitrogen $($ ) $-5 \mu$; TAQ Platinum DNA polymerase 5UI (GIBCO $\left.{ }^{\circ}\right)-0.3 \mu \mathrm{l}$; primers $(20 \mu \mathrm{M})$ (pool) (Invitrogen $\left.{ }^{\circledR}\right)-2 \mu \mathrm{l} ; \mathrm{MgCl}_{2}\left(50 \mathrm{mM}\right.$ - Invitrogen $\left.{ }^{\circledR}\right)$ $1.5 \mu \mathrm{l} ; \mathrm{H}_{2} \mathrm{O}$ DNAse/RNAse free $-27.2 \mu \mathrm{l}$ and the NESTED one: dNTP's (2.5 mM - Invitrogen $\left.{ }^{\circledR}\right)-4 \mu \mathrm{l}$; 10X buffer (Invitrogen $\left.{ }^{\circledR}\right)-5 \mu \mathrm{l} ; \mathrm{MgCl}_{2}(50 \mathrm{mM}$ Invitrogen $(\mathbb{B})-1.5 \mu \mathrm{l}$; TAQ Platinum DNA polymerase 5UI (GIBCO®) - $0.3 \mu \mathrm{l}$; primers $(20 \mu \mathrm{M}$ - pool Invitrogen ()$-2 \mu \mathrm{l} ; \mathrm{H}_{2} \mathrm{O}$ DNAse/RNAse free $-32.2 \mu \mathrm{l}$. (Cinque et al. 1993).

\section{RESULTS}

The clinical examination of all subjects from groups $\mathrm{A}, \mathrm{B}$, and $\mathrm{C}$ showed that the tongue and oral mucosa were normal. In the positive control group (group D), 11 patients $(36.5 \%)$ presented a white lesion on borders of the tongue. Among these, 5 (16.5\%) were bilateral, $3(10 \%)$ on the right border and $3(10 \%)$ on the left border.

All samples presented enough material to cytopathological analysis, and the majority of them were considered of normal pattern (Table II). In groups A, B, and $\mathrm{C}$ only one case of OHL associated with candidiasis was identified (Fig.1) and two cases of candidiasis, both in the diabetic group.

The PCR method (Fig. 2) used identified epithelial infection on the lateral border of the tongue in 7 (35\%) of 20 selected diabetics; 13 (65\%) of 20 pregnant women and in $2(20 \%)$ of 10 selected healthy individuals (Fig. 3). Comparing the percentage of EBV-DNA by PCR between pregnant women and diabetics, we found that 
TABLE II

Cytopathologic diagnoses

\begin{tabular}{lcccc}
\hline Group & NP $(\%)$ & Inflammation $(\%)$ & Candidiasis $(\%)$ & OHL $(\%)$ \\
\hline A & $77(86)$ & $11(12)$ & $2(2)$ & $1(1)$ \\
B & $77(86)$ & $13(14)$ & - & - \\
C & $30(87)$ & - & - & - \\
D & - & - & $9(30)$ & $30(100)$ \\
\hline
\end{tabular}

A: diabetics; B: pregnant women; C: negative control; D: positive control; NP: normal pattern; OHL: oral hairy leukoplakia.
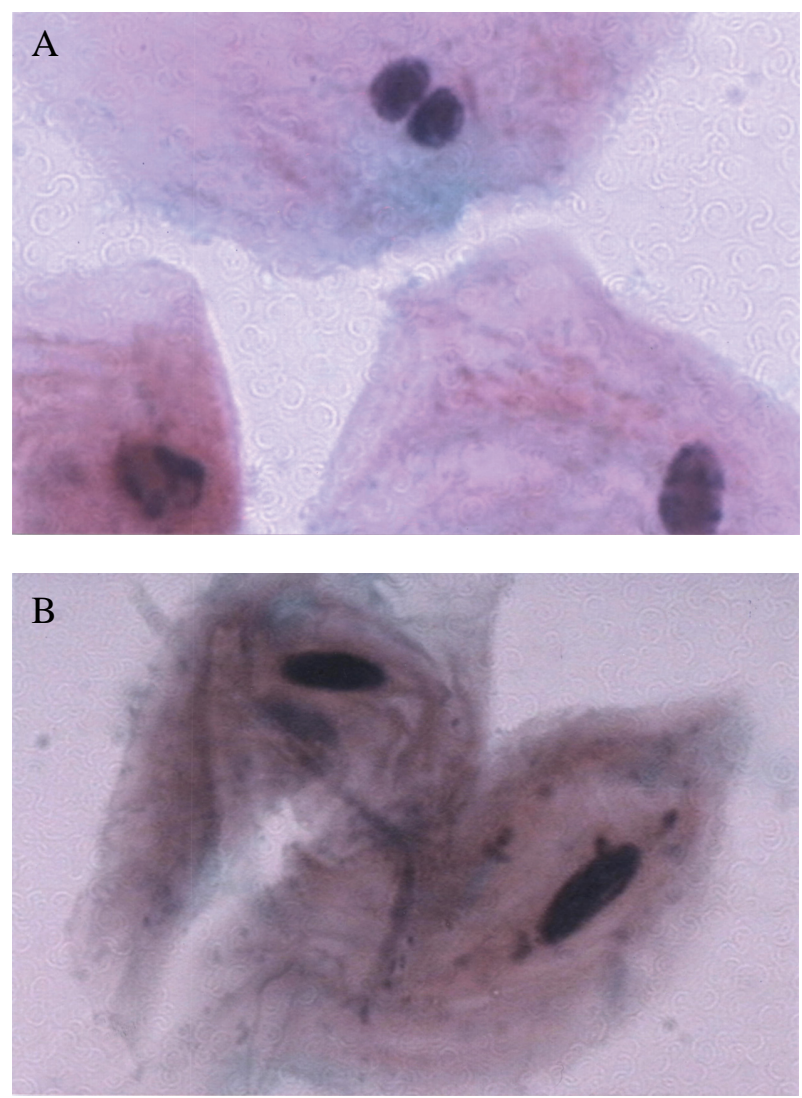

Fig. 1: oral hairy leukoplakia associated with candidiasis in diabetes mellitus patient. Smears (Papanicolaou, 1000x) showing: A: nuclei alterations - Cowdry type A inclusion and nuclear beading; B: candidiasis.

there is no representative difference in the proportions of patients with EBV-DNA in the two groups (Fisher Exact Test, $p>0.05$ ). On the other hand, the proportion of pregnant women to healthy individuals showed that the former is statistically bigger $(65 \%)$ than the latter $(20 \%)$ (Fisher Exact Test, p value $=0.025)$. Likewise, comparing diabetic and healthy subjects, no significant difference was detected (Fisher Exact Test, $\mathrm{p}>0.05$ ). All EBV-DNA negative samples were tested for $\beta$-globin and presented a positive result.

\section{DISCUSSION}

Although OHL and candidiasis are not considered lesions associated with an important morbidity or mortality, they are important hallmarks of immunodeficiency, specially in HIV infection (Cherry-Peppers et
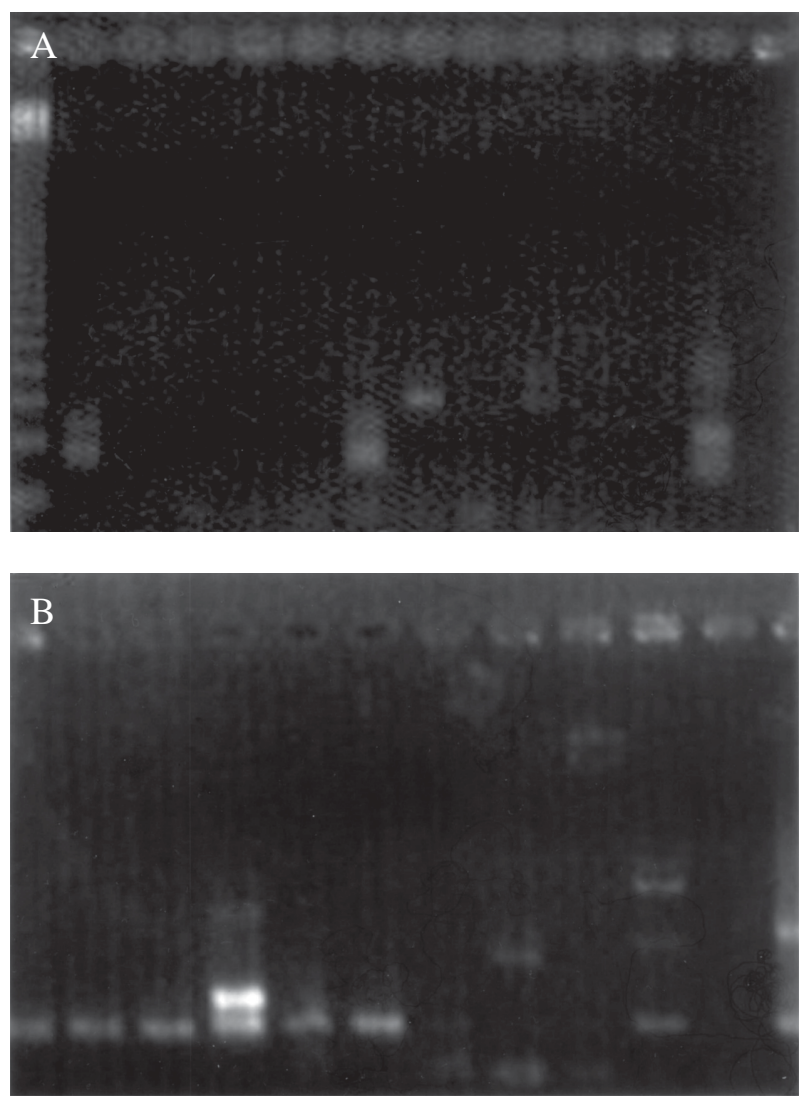

Fig. 2: polymerase chain reaction result. Gel electrophoresis showing EBV amplicons (on the left) and a positive control (on the right - samples of HIV+ patients); $\mathrm{M}=123 \mathrm{bp}$ DNA ladder marker; A: two positive samples of healthy individuals; B: seven positive samples of pregnant women.

al. 2003, Greenspan et al. 2004, Chattopadhyay et al. 2005). The etiology of OHL has already been established, and EBV can be identified through electronic microscopy, in situ hybridization, immunohistochemistry, and PCR (Fraga-Fernández \& Vicandi-Plaza 1992, Mabruk et al. 1995, Greenspan et al.1998, Gulley 2001). However, those techniques are very complex and expensive. The nuclear changes that represent EBV cytopathic effects can be visualized by histopathology and cytopathology (Fraga-Fernández et al. 1990, Fraga-Fernández \& Vicandi-Plaza 1992, Migliorati et al. 1993, Dias et al. 1999, 2000).

Considering that biopsy is an invasive procedure, we suggest that cytopathology should be the best choice to diagnose OHL. Among the advantages of the routine smears of the lateral border of the tongue for cytopatho- 


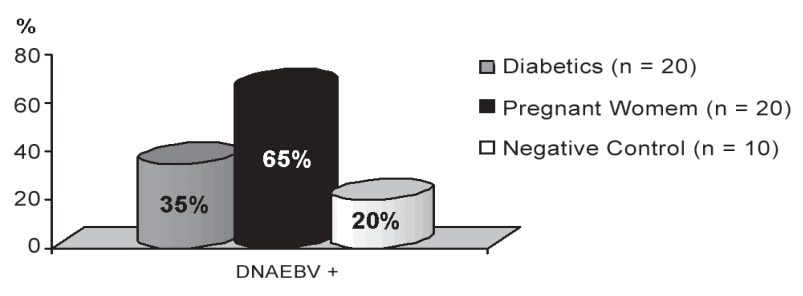

Fig. 3: results of polymerase chain reaction.

logical exam are: (a) the diagnosis of inflammatory changes with the identification of the etiological agent (fungus and some bacteria) or cytopathic effects (HSV, CMV, EBV); (b) oncologic analysis of epithelial cells; (c) the possibility to use the material in different methods, including molecular and electronic microscopy studies.

The development of OHL and candidiasis in patients with severe immunodeficiency, as in HIV seropositive, organ-transplanted subjects and in individuals presenting malignant neoplasias, is already well documented in the literature (Blomgren \& Bäck 1996, Ammatuna et al. 2001, Casiglia \& Woo 2002). Conversely, a relevant fact is that OHL findings in HIV seronegative patients, with low or moderate immunosuppression, or even in clinically healthy individuals are scarce (Eisenberg et al. 1992, Felix et al. 1992, Lozada-Nur et al. 1994, Schiodt et al. 1995, Zakrzewska et al. 1995). Considering the importance of candidiasis and OHL as markers and EBV association to several malignant neoplasias, it is pertinent to identify the frequency of EBV infection and candidiasis not only in healthy individuals, but also in those showing different degrees of immunosuppression.

Our research grouped an important number of HIV-1 seronegative individuals $(n=210)$, being the first study to investigate the presence of OHL in diabetics and pregnant women. From this casuistic, 50 (24\%) cases were submitted to EBV-DNA identification by PCR. OHL and candidiasis were identified only among diabetics and in a prevalence of 1 and $2 \%$, respectively. The only case of OHL identified among all the samples studied, was related to a subclinic lesion in a 75-year-old diabetic man, who presented a hyperglycemic condition and chronic obstructive pulmonary disease since 1995, taking oral and systemic steroid ( $40 \mathrm{mg} /$ day), characterizing a second condition of immunosuppression. These results are in agreement to the literature that considers OHL and candidiasis hallmarks of severe immunosuppression (Cherry-Peppers et al. 2003, Greenspan et al. 2004, Chattopadhyay et al. 2005).

Studies reveal a high prevalence of oral candidiasis in diabetics. Amato and Pecora (1983) analyzing 50 DM type II patients, without any lesion on the oral cavity, identified Candida albicans hyphae in the saliva of 25 (50\%) patients. Willis et al. (1999) demonstrated the presence of $C$. albicans in 77\% of 414 DM patients using insulin, from which $40 \%$ did not present any clinical manifestation of candidiasis. Redinova and Zlobina (2002) performed an oral exam in 102 DM types I and II patients with, attesting the incidence of $C$. albicans in
$78.4 \%$, among these only $35 \%$ presented lesion on oral mucosa. Surprisingly, we identified only two cases (2.2\%) without clinical manifestation of the lesion. One possible explanation for that can be related to the fact that we performed the examinations in a group of stable patients that received regular outpatient medical care and psycho-nutritional orientation.

The prevalence of EBV on the tongue of healthy individuals, by PCR, varies from 10 to $90 \%$. Mabruck et al. (1994), collected material from the lateral border of the tongue of 10 healthy patients, where they identified EBV-DNA in $9(90 \%)$ of 10 cases. In the same way, Scully et al. (1998), identified in cytological smears of the tongue EBV-DNA in $4(20 \%)$ out of 20 healthy subjects. Ammatuna et al. (2001), studying 30 healthy individuals who presented normal tongue clinical aspect, detected by PCR, EBV-DNA in $3(10 \%)$ individuals. The major sample studied was published by Triantos et al. (1998) and included 40 individuals, where EBV was identified in the epithelial cells of the tongue in $4(10 \%)$. Consequently, EBV identification in $20 \%$ of healthy individuals of our study is in accordance with the few studies already mentioned.

This is the first study that investigates the presence of EBV-DNA on smears of the lateral border of the tongue of diabetics $(35 \%)$ and pregnant women $(65 \%)$. Our results showed an increase in the percentage of latent EBV infected patients, on the lateral border of the tongue, when compared to the percentage identified among healthy individuals. In pregnant women, it is reported only serological analyses, which in large series identify an average prevalence of EBV of $98 \%$ (Icart et al. 1981, Fleisher \& Bolognese 1982, Le et al. 1983). Notwithstanding, in diabetics, serological studies are rare. (Hyoty et al. 1991, Jaeckel et al. 2002).

The PCR analysis has called our attention because there were positive cases in only one of the borders of the tongue. All negative samples regarding the presence of EBV-DNA, were $\beta$-globin positive, that is, all of them presented enough material for analysis. This result may justify the unilateral identification of the OHL, clinical or subclinical, in several $\mathrm{HIV}^{+}$patients. In addition, it suggests that EBV-DNA was not in the saliva; otherwise both samples should be positive.

The results showed that EBV infection on smears of the lateral border of the tongue of individuals with minor immunodeficiency such as pregnant women and diabetics is considerably higher than in healthy subjects. Considering OHL a probable marker of immunodeficiency, PCR analysis to diagnose EBV latent infection and cytopathology to follow a possible passage to replicative phase could be useful in patients with different degrees of immunodeficiency. We believe that the investigation of the prevalence of $E B V$ infection in the keratinocytes of the tongue, with proper identification of viral burden and respective phase of the infection, will determine the real contribution of OHL and EBV infection as markers of immunodeficiency and it would be an alternative tool in patients' clinical follow up. 


\section{REFERENCES}

Amato R, Pecora A 1983. Incidence of oral candidiasis in a sample group of diabetics. Boll Soc Ital Biol Sper 30: 532-534.

Ammatuna P, Campisi G, Giovannelli L, Giambelluca D, Alaimo C, Mancuso S, Margiotta V 2001. Presence of Epstein-Barr virus, cytomegalovirus and human papillomavirus in normal oral mucosa of HIV-infected and renal transplant patients. Oral Dis 7: 34-40.

Blomgren J, Bäck H 1996. Oral hairy leukoplakia in a patient with multiple mieloma. Oral Surg Oral Med Oral Pathol Oral Radiol Endod 82: 408-410.

Casiglia J, Woo S-B 2002. Oral hairy leukoplakia as a nearly indicator of Epstein-Barr viru-associated post-transplant lymphoproliferative disorder. J Oral Maxillofac Surg 60: 948-950.

Chattopadhyay A, Caplan D J, Slade G D, Shugars DC, Tien HC, Patton LL 2005. Incidence of oral candidiasis and hairy leukoplakia in HIV-infected adults in North Carolina. Oral Surg Oral Med Oral Pathol Oral Radiol Edond 99: 39-47.

Cherry-Peppers G, Daniels CO, Meeks V, Sanders CF, Reznik D 2003. Oral manifestations in the era of HAART. $J$ Natl Med Assoc 95: 21-32.

Cinque P, Brytting M, Vago L, Castagna A, Parravicini C, Zanchetta N, D'Arminio, Monfort A, Wahren B, Lazzarin A, Linde A 1993. Epstein-Barr virus DNA in cerebrospinal fluid from patients with AIDS-related primary lymphoma of the central nervous system. The Lancet 342: 398-401.

Dias EP, Rocha ML, Silva Júnior A, Spyrides KS, Ferreira SM, Polignano GA, Feijo EC, Da Fonseca EC 2000. Oral hairy leukoplakia - Histophatologic and cytopathologic features of a subclinical phase. Am J Clin Pathol 114: 394-400.

Dias EP, Silva Junior A, Feijó EC, Polignano GAC 1999. Diagnóstico citopatológico da leucoplasia pilosa. J Bras Patol Med Lab 35: 23-28.

Eisenberg E, Krutchkof FD, Yamase H 1992. Incidental oral hairy leukoplakia in immunocompetent persons. Oral Surg Oral Med Oral Pathol 74: 332-333.

Felix DH, Watret K, Wray D, Southam JC 1992. Hairy leukoplakia in a HIV-negative nonimmunosuppressed patient. Oral Surg Oral Med Oral Pathol 74: 563-566.

Ferres M, Prado P, Ovalle J, Fuentes R, Villarroel L, Ferreccio C, Vial P 1995. Seroprevalence of Epstein-Barr virus infection in a healthy population of Santiago de Chile. Rev Med Chil 123: 1447-1452.

Fleisher GR, Bolognese R 1982. Seroepidemiology of EpsteinBarr virus in pregnant women. J Infect Dis 145: 537-541.

Fraga-Fernández J, Vicandi-Plaza B 1992. Diagnosis of hairy leukoplakia by exfoliative cytologic methods. Am J Clin Pathol 97: 262-266.

Fraga-Fernández J, Benito C, Lizaldez EB 1990. Oral hairy leukoplakia: a histopathologic study of 32 cases. Am J Dermatopathol 12: 571-578.

Greenspan D, Gange SJ, Phelan JA, Navazesh M, Alves ME, MacPhail LA, Mulligan R, Greenspan JS 2004. Incidence of oral lesions in HIV-1-infected women: reduction with HAART. J Dent Res 83: 145-150.

Greenspan JS, De Souza YG, Regezi JA, Daniels TE, Greenspan D, MacPhail LA, Hilton JF 1998. Comparison of cytopathic changes in oral hairy leukoplakia with in situ hybridization for EBV DNA. Oral Dis 4: 95-99.

Gulley ML 2001. Molecular diagnosis of Epstein-Barr virus Related diseases. J Mol Diag 3: 1-10.

Hyoty H, Rasanen L, Hiltunen M, Lehtinen M, Huupponen T, Leinikk P 1991. Decreased antibody reactivity to EpsteinBarr virus capsid antigen in type 1 (insulin-dependent) diabetes mellitus. APMIS 99: 359-363.

Icart J, Didier J, Dalens M, Chabanon G, Boucays A 1981. Prospective study of Epstein-Barr virus (EBV) infection during pregnancy. Biomedicine 34: 160-163.

Jaeckel E, Manns M, Von Herrat M 2002. Viruses and diabetes. Ann NY Acad Sci 958: 7-25.

Le CT, Chang RS, Lipson MH 1983. Epstein-Barr virus infections during pregnancy. Am J Dis Child 137: 466-468.

Lozada-Nur F, Robinson J, Regezi JA 1994. Oral hairy leukoplakia in nonimmunosuppressed patiens - Report of four cases. Oral Surg Oral Med Oral Pathol 78: 599-602.

Mabruk MJ, Flint SR, Torner M, Balluz I Coleman DC, Sullivan D, Atkins GJ 1994. In situ hybridization and the polimerase chain reaction (PCR) in the analysis of biopsies and exfoliative cytology specimens for definitive diagnosis of oral hairy leukoplakia (OHL). J Oral Pathol Med 23: 302-308.

Mabruk MJ, Flint SR, Torner M, Leonard N, Sheils O, Coleman DC, Atkins GJ 1995. Detection of Epstein-Barr virus DNA in tongue tissues from AIDS autopsies without clinical evidence of oral hairy leukoplakia. J Oral Pathol Med 24: 109-112.

Migliorat CA, Jones AC, Baughman P 1993. Use of exfoliative cytology in the diagnosis of oral hairy leukoplakia. Oral Surg 76: 704-710.

Nakamura N, Miyazaki K, Kitano Y, Fujisaki S, Okamura H 1993. Suppression of cytotoxic T-lymphocyte activity during pregnancy. J Reprod Immuno 23: 119-130.

Ozkan A, Kilic SS, Kalkan A, Ozden M, Demirdag K, Ozdarendeli A 2003. Seropositivity of Epstein-Barr virus in Eastern Anatolian Region of Turkey. Asian Pac J Allergy Immunol 21: 49-53.

Pancharoen C, MekmullicA J, Chinratanapisit S, Bhattarakosol P, Thisyakom U 2001. Seroprevalence of Epstein-Barr virus antibody among children in various age groups in Bangkok, Thailand. Asian Pac J Allergy Immunol 19: 135-137.

Priddy KD 1997. Immunologic adaptations during pregnancy. J Obstet Gynecol Neonatal Nurs 26: 388-394.

Read SJ, Jeffery KJM, Bangham CRM 1997. Aseptic meningitis and encephalitis: the role of PCR in diagnostic laboratory. J Cli Microbiol 35: 691-695.

Redinova TL, Zlobina AO 2002. Incidence of candidiasis of the buccal mucosa and efficiency of its treatment in diabetics. Stomatologiia (Mosk) 80: 20-22.

Sand LP, Jalouli J, Larsson PA, Hirsch JM 2002. Prevalence of Epstein-Barr virus in oral squamous cell carcinoma, oral lichen planus, and normal oral mucosa. Oral Surg Oral Med Oral Pathol Oral Radiol Edond 93: 586-592.

Schmidt-Westhausen A, Gelderblom HR, Neuhaus P, Reichart PA 1993. Epstein-Barr virus in lingual epithelium of liver transplant patients. J Oral Pathol Med 22: 274-276. 
Schiodt M, Norgaard T, Greenspan JS 1995. Oral hairy leukoplakia in an HIV-negative woman with Behçet's syndrome. Oral Surg Oral Med Oral Pathol 79: 53-56.

Scully C, Porter SR, Di Albert L, Jalal M, Maitland N 1998. Detection of Epstein-Barr virus in oral scrapes in HIV infection, in hairy leukoplakia, and in healthy non-HIV-infected people. J Oral Pathol Med 27: 480-482.

Stiehm R, Fulginiti V 1980. Immunologic Disorders in Infants and Children, Sauders, Philadelphia.
Triantos D, Leao JC, Porter SR, Scully CM, Teo CG 1998. Tissue distribtion of Epstein- Barr vírus genotypes in hosts coinfection by HIV. AIDS 12: 2141-2146.

Willis AM, Coulter WA, Fulton CR, Hayes JR, Bell PM, Lamey PJ 1999. Oral candidal carriage and infection in insulin-treated diabetic patients. Diabet Med 16: 675-679.

Zakrzewska JM, Aly Z, Speight PM 1995. Oral hairy leukoplakia in a HIV-negative asthmatic patient on systemic steroids. J Oral Pathol Med 24: 282-284. 